\title{
Motivasi Petani dalam Usahatani Bawang Putih (Allium sativum) di Kecamatan Tawangmangu, Kabupaten Karanganyar
}

\section{Farmer Motivation In Garlic Farming (Allium Sativum) In Tawangmangu Sub-District Karanganyar Regency}

Udi Arga*, Retno Setyowati, Sapja Anantanyu

Program Studi Penyuluhan dan Komunikasi Pertanian, Fakultas Pertanian, Universitas Sebelas Maret Surakarta, Indonesia

*email: udiarga@gmail.com

I N F O A R T I K E I

Sejarah artikel:

Dikirim 13 Desember 2020

Diterima 16 Februari 2021

Terbit 26 April 2021

\section{Kata kunci: \\ Petani \\ Usahatani \\ Motivasi Petani \\ Bawang Putih}

Keywords:
Farmer
Farming
Motivation of Farmers
Garlic

A B S T R A K

Bawang putih termasuk komoditas yang dapat diunggulkan dan dikembangkan di Kecamatan Tawangmangu. Motivasi petani sebagai pengelola usahatani merupakan suatu kondisi yang mendorong dan mempengaruhi petani melakukan tindakan, apa yang mendasari petani dalam melakukan usahatani bawang putih, sedangkan risiko dalam menanam bawang putih juga tinggi, dan keuntungan apa yang didapatkan dari usahatani ini. Tujuan penelitian untuk mengetahui : (1) motivasi petani dalam usahatani tanaman bawang putih; (2) faktor yang mempengaruhi motivasi petani; (3) hubungan antara faktor yang mempengaruhi motivasi dengan motivasi petani dalam usahatani tanaman bawang putih. Metode penelitian adalah metode kuantitatif dengan teknik survei. Penelitian berlokasi di Kecamatan Tawangmangu Kabupaten Karanganyar. Pengambilan sampel menggunakan teknik accidental sampling sebanyak 50 petani. Hasil penelitian menunjukkan bahwa : (1) kebutuhan sosial mendominasi tingkat motivasi petani dalam usahatani tanaman bawang putih; (2) faktor pembentuk motivasi yaitu umur dalam kategori lansia awal, pendidikan formal rendah, luas lahan tinggi, pendapatan sangat rendah, pengalaman sangat tinggi, lingkungan sosial rendah, lingkungan ekonomi rendah, kelembagaan kelompok tani tinggi, dan dukungan pemerintah/swasta rendah; (3) Terdapat hubungan yang sangat signifikan antara faktor pendapatan, lingkungan sosial, dan lingkungan ekonomi dengan motivasi petani dalam usahatani tanaman bawang putih. Terdapat hubungan yang signifikan antara faktor luas lahan, kelembagaan kelompok tani dan dukungan pemerintah/swasta dengan motivasi petani dalam usahatani tanaman bawang putih. Tidak terdapat hubungan signifikan antara faktor umur, pendidikan dan pengalaman dengan motivasi petani dalam usahatani tanaman bawang putih.

\section{$\boldsymbol{A} \boldsymbol{B} \boldsymbol{S} \boldsymbol{T} \boldsymbol{R} \boldsymbol{A} \boldsymbol{C} T$}

Garlic is a commodity that can be seeded and developed in Tawangmangu District. The motivation of farmers as farm managers here is defined as the conditions that encourage farmers to take action, what underlies the farmers in doing garlic farming, while the risk in planting garlic is also high, and what benefits can be obtained from this farming. The objectives of the study were to determine: (1) the motivation of farmers in garlic farming; (2) factors that influence the motivation of farmers; (3) the relationship between the factors that influence motivation and the motivation of farmers in garlic farming. The method used is a quantitative method with a survey technique. The research is located in Tawangmangu District, Karanganyar Regency. Sampling using accidental sampling technique as many as 50 farmers. The results showed that: (1) social needs dominate the level of motivation of farmers in garlic farming; (2) motivation-forming factors, namely age in the category of early elderly, low formal education, high land area, very low income, very high experience, low social environment, low economic environment, high farmer group institutions, and low government/private support; (3) There is a very significant relationship between income factors, social environment, and economic environment with the motivation of farmers in garlic farming. There is a significant relationship between the factors of land area, farmer group institutions 
and government/private support with the motivation of farmers in garlic farming.

There is no significant relationship between the factors of age, education and experience with the motivation of farmers in farming garlic.

\section{PENDAHULUAN}

Indonesia mempunyai banyak potensi keanekaragaaman dan sumber daya alam melimpah untuk produk-produk pertanian dan memiliki beragam jenis tanaman, hal ini dipengaruhi kondisi iklim tropis yang mendukung variasi tanaman tersebut, salah satu komoditas unggulannya yaitu bawang putih (Allium sativum). Daerah Tawangmangu sudah dikenal sebagai daerah komoditas unggulan bawang putih (Allium sativum). Petani bawang putih di Kecamatan Tawangmangu menanam tanaman bawang putih sudah sejak tahun 1980-an dan tetap melakukan usahatani hingga sekarang karena adanya budaya turun-temurun untuk menanam bawang putih, selain itu adanya keuntungan yang tinggi dalam berusahatani bawang putih membuat petani tetap menanam tanaman tersebut hingga sekarang. Berdasarkan data Luas Panen dan Produksi Tanaman Sayur-sayuran menurut Kecamatan di Kabupaten Karanganyar Tahun 2017, Produksi bawang putih di Kabupaten Karanganyar tahun 2017 mencapai jumlah $8.009 \mathrm{kw}$ dengan luas panen $73 \mathrm{Ha}$, untuk Produksi bawang putih di Kecamatan Tawangmangu sendiri yaitu $6.864 \mathrm{kw}$ dengan luas panen 48 Ha. Data tersebut mengalami kenaikan di Tahun 2018, Produksi bawang putih di Kabupaten Karanganyar tahun 2018 mencapai jumlah 16.779 kw dengan luas panen $206 \mathrm{Ha}$, untuk Produksi bawang putih di Kecamatan Tawangmangu sendiri yaitu $14.119 \mathrm{kw}$ dengan luas panen 108 Ha. Tahun 2019 juga mengalami peningkatan. Produksi bawang putih di Kabupaten Karanganyar tahun 2019 mencapai 27.622 kw dengan luas panen 479 Ha, untuk Produksi bawang putih di Kecamatan Tawangmangu sendiri yaitu $21.812 \mathrm{kw}$ dengan luas panen $155 \mathrm{Ha}$. Berdasarkan data tersebut dapat diketahui jika Produktivitas bawang putih di Kabupaten Karanganyar mengalami peningkatan, dengan Kecamatan Tawangmangu yang menunjukan angka produktivitas yang paling tinggi diantara kecamatan lainnya. Peningkatan produktivitas tersebut dapat dipengaruhi oleh berbagai faktor baik faktor dari dalam (internal) maupun faktor dari luar (eksternal) yang berpengaruh pada motivasi petani dalam usahatani bawang putih di Kecamatan Tawangmangu.

Motivasi pada petani tidak hanya meliputi pemenuhan kebutuhan hidup petani, namun juga berpengaruh pada peningkatan dalam penyediaan fasilitas-fasilitas penunjang lainnya seperti saranaprasarana produksi pertanian. Motivasi petani sebagai pengelola usahatani di sini dimaksudkan sebagai kondisi yang mendorong petani untuk melakukan tindakan, apa yang mendasari petani dalam melakukan usahatani bawang putih karena jika dilihat pada data Luas Panen dan Produksi Tanaman Sayur sayuran menurut Kecamatan di Kabupaten Karanganyar selalu mengalami peningkatan produksi sedangkan risiko dalam menanam bawang putih juga tinggi terlebih juga tantangan pemasaran yang harus dilakukan di saat pandemi, kemudian apa saja keuntungan yang benar-benar di terima oleh petani. Faktor lain yang menjadi alasan mengapa dilakukannya penelitian tentang motivasi selain dari adanya peningkatan produksi dan luas panen bawang putih, adanya tren naik turunnya produktivitas bawang putih dari tahun 2015-2019, keuntungan petani dalam melakukan bawang putih baik keuntungan dari pendapatan dan keuntungan lainnya, serta adanya faktor turun temurun untuk menanam bawang putih juga di dasari dari penting adanya sebuah analisis yang berkaitan dengan motivasi petani dalam rangka mengetahui sejauh mana dorongan serta keinginan petani dalam berusahatani bawang putih. Penelitian ini bertujuan untuk menganalisis motivasi petani dalam usahatani tanaman bawang putih, menganalisis faktor-faktor yang mempengaruhi motivasi petani dalam usahatani tanaman bawang putih, dan menganalisis hubungan antara faktor-faktor yang mempengaruhi motivasi dengan motivasi petani dalam usahatani tanaman bawang putih.

\section{METODE}

Metode dasar yaitu metode kuantitatif dengan teknik survei. Penentuan lokasi dilakukan secara sengaja di Kecamatan Tawangmangu Kabupaten Karanganyar. Populasi dalam penelitian adalah petani bawang putih di dua desa pada wilayah Kecamatan Tawangmangu yang menjadi sentra terbesar penghasil bawang putih yaitu di Desa Kalisoro dan Desa Blumbang. Pengambilan sampel menggunakan teknik accidental sampling dan responden diambil sebanyak 50 petani. Jenis data yang digunakan adalah kuantitatif dan kualitatif, serta sumber data primer dan sekunder. Teknik pengumpulan data dilakukan dengan cara wawancara, observasi, pencatatan dan dokumentasi dengan instrumen penelitian yaitu 
kuesioner. Pengukuran instrumen penelitian (kuesioner) menggunakan uji validitas dan reliabilitas. Analisis data menggunakan uji lebar interval pembagian kategori dengan kategori sangat tinggi, tinggi, rendah dan sangat rendah, rumus lebar interval, yaitu:

$$
\text { Lebar interval kelas }(i)=\frac{\sum \text { skor tertinggi }-\sum \text { skor terendah }}{\sum \text { kelas }}
$$

Untuk menguji hubungan antara variabel umur (X1), pendidikan formal (X2), luas lahan (X3), pendapatan (X4), pengalaman (X5), lingkungan sosial (X5), lingkungan social (X6), lingkungan ekonomi (X7), kelembagaan kelompok tani (X8) dan dukungan pemerintah /swasta (X9) dengan variabel motivasi petani dalam usahatani tanaman bawang putih, menggunakan uji korelasi rank spearman $\left(r_{s}\right)$ dengan program IBM SPSS Statistics.

Rumus korelasi Rank Spearman (rs) adalah :

$$
r_{S}=1-\frac{6 \sum_{i=1}^{N} d_{i}^{2}}{N^{3}-N}
$$

Keterangan :

$r_{s}:$ Koefisien korelasi

di : selisih dari masing-masing variabel $(\mathrm{X}-\mathrm{Y})$

$\mathrm{n}$ : jumlah sampel

Tingkat signifikansi rs diuji dengan tingkat kepercayaan 95\%. Arah hubungan akan mempunyai arti jika hubungan antar variabel tersebut bernilai signifikan. Dikatakan hubungan yang signifikan, yaitu: (1) Apabila sig. (2-tailed) $\geq \alpha=0,05$ maka $\mathrm{H} 0$ diterima/Ha ditolak yang berarti tidak terdapat hubungan yang signifikan. (2) Apabila sig. (2-tailed) $<\alpha=0,05$ maka $\mathrm{H} 0$ ditolak/Ha diterima yang berarti terdapat hubungan yang signifikan.

\section{HASIL DAN PEMBAHASAN}

\subsection{Faktor-faktor Pembentuk Motivasi Petani dalam Usahatani Tanaman Bawang Putih di Kecamatan Tawangmangu Kabupaten Karanganyar}

Umur dijelaskan sebagai waktu hidup petani responden sampai penelitian ini dilakukan yang dapat dilihat pada Gambar 1. Gambar 1 menunjukkan bahwa responden didominasi oleh usia 46-55 dengan jumlah 33 orang (66 persen). Petani dengan rentang usia 46-55 tahun memiliki pemikiran yang lebih terbuka dan semangat lebih tinggi atau rasa keingintahuan yang lebih serta lebih mudah untuk dibekali keterampilan maupun pengetahuan, mempunyai kemampuan fisik yang kuat dalam mengembangkan usahataninya. Hasyim (2006) mengatakan umur petani dapat dijadikan sebagai tolak ukur dalam melihat aktivitas petani dalam kegiatan usahatani, di mana dengan kondisi umur petani yang masih produktif, kemungkinan besar petani dapat bekerja dengan baik secara maksimal.

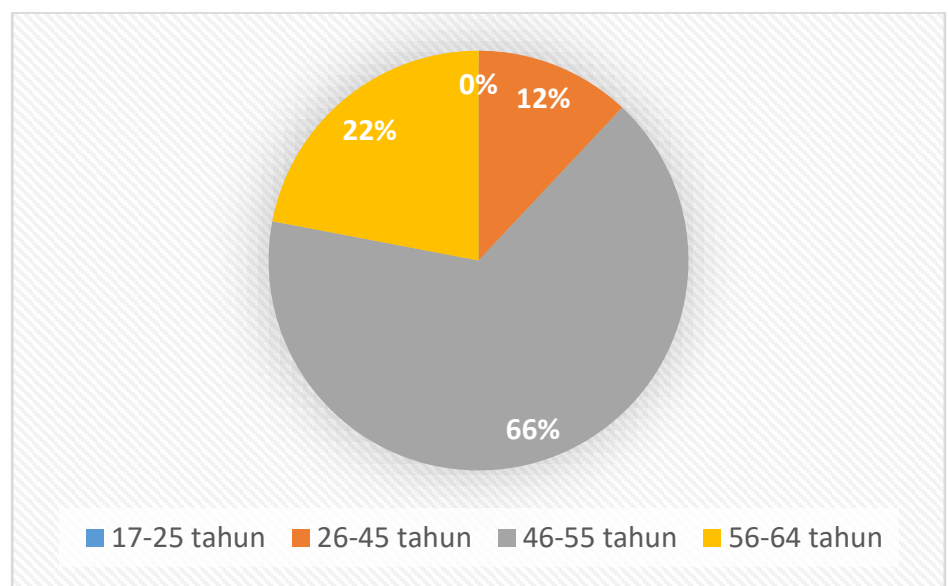

Gambar 1. Distribusi responden berdasarkan umur

Pendidikan formal dijelaskan sebagai tingkat pendidikan yang ditamatkan oleh petani responden pada pendidikan formal, dapat dilihat pada Gambar 2. Berdasarkan Gambar 2 dapat 
diketahui mayoritas responden memiliki tingkat Pendidikan yang sangat rendah dengan jumlah 38 orang (76 persen) dengan pencapaian pendidikan formal di bangku SD. Petani melakukan usahatani karena faktor turun temurun, sehingga pada zaman dahulu responden petani lebih mementingkan membantu orang tua di lahan dibandingkan dengan melanjutkan bersekolah pada tingkat selanjutnya. Hasyim (2003) menjelaskan jika tingkat pendidikan formal petani dapat mempengaruhi dan menunjukkan tingkat pengetahuan maupun wawasan yang luas untuk petani dalam menerapkan apa yang diperolehnya guna meningkatkan usahataninya.

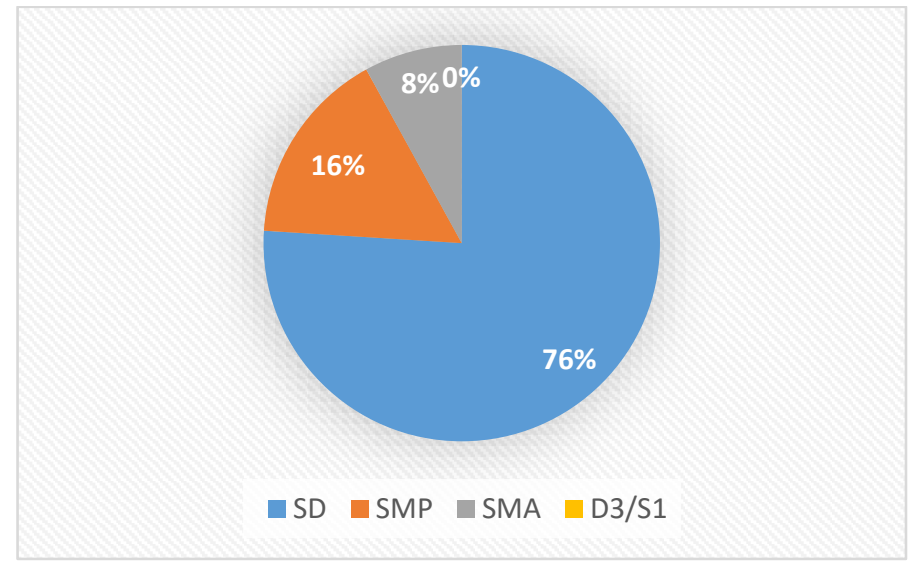

Gambar 2. Distribusi petani responden berdasarkan pendidikan formal

Gambar 3 dapat diketahui bahwa luas lahan petani responden dalam usahatani tanaman bawang putih masuk dalam kategori tinggi yaitu sebanyak 26 orang responden (52 persen). Kecamatan Tawangmangu merupakan daerah potensial untuk menjadi lahan pertanian maka dari itu petani akan memaksimalkan kepemilikan lahan mereka untuk ditanami tanaman bawang putih. Menurut Daniel (2002) luas lahan pertanian menjadi dasar yang sangat penting dalam proses produksi atau pun usahatani. Semakin luas lahan yang digarap petani untuk usahatani, makan semakin besar produksi pertanian yang diperoleh.

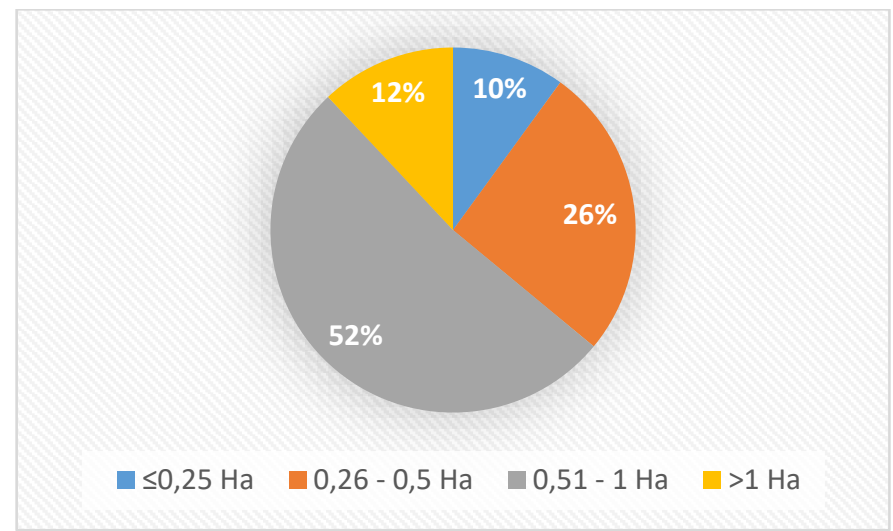

Gambar 3. Distribusi responden berdasarkan luas kepemilikan lahan

Pendapatan dinyatakan dalam berapa total jumlah pendapatan petani mereka peroleh dari usahatani bawang selama satu kali musim tanam dan dapat dilihat pada Gambar 4. Gambar 4 menunjukkan besar pendapatan keluarga responden petani sebanyak 24 orang (48 persen) berada pada kategori sangat rendah di mana rata-rata pendapatan satu musim $\mathrm{Rp}<\mathrm{Rp} .2 .999 .000$. Hal ini disebabkan karena pada musim panen terakhir petani responden mengatakan jika rata-rata petani bawang putih mengalami kegagalan panen karena cuaca saat melakukan usahatani tidak mendukung. Menurut Phahlevi (2007) sektor pertanian memiliki peranan penting sebagai sumber pendapatan utama bagi petani, para petani pada umumnya memproduksi hasil pertanian untuk pemenuhan kebutuhan hidup sehari-hari. 


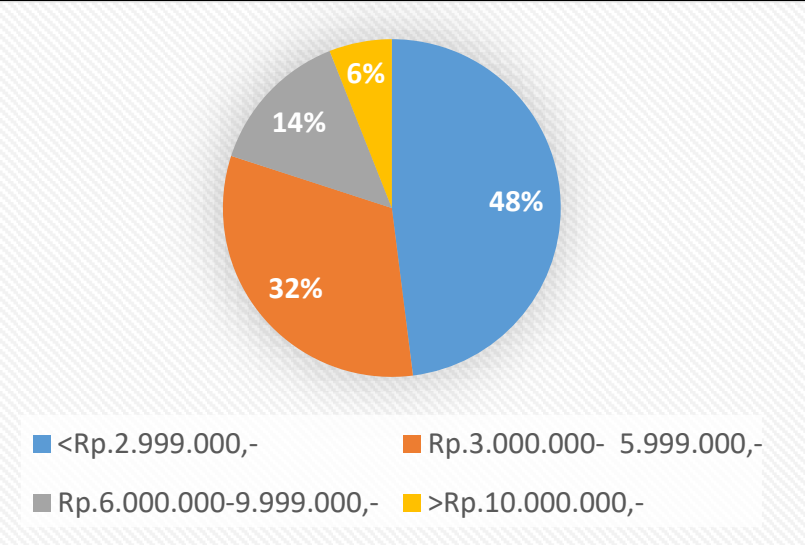

Gambar 4. Distribusi Responden Berdasarkan Pendapatan

Berdasarkan Gambar 5 menunjukkan bahwa terdapat 35 orang (70 persen) pengalamannya berada dalam kategori sangat tinggi dengan kurun waktu responden dalam berusahatani tanaman bawang putih lebih dari 20 tahun. Lamanya budidaya akan memberikan pembelajaran dalam melakukan usahatani bawang putih. Menurut Arifin et al. (2017) pengalaman petani dalam kegiatan berusahatani dapat mendorong petani untuk tetap mengelola usahatani agar terus berkesinambungan dan memperkaya pengetahuannya serta meningkatkan keterampilannya.

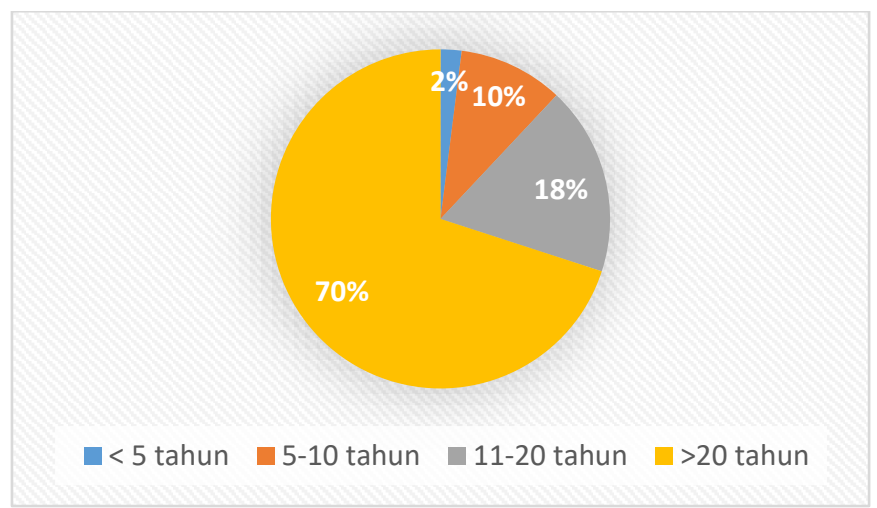

Gambar 5. Distribusi responden berdasarkan pengalaman usahatani

Lingkungan sosial diartikan sebagai lingkungan masyarakat sekitar yang dapat memberikan dukungan maupun bantuan baik secara langsung maupun tidak langsung dalam usahatani dan dapat dilihat pada Gambar 6. Berdasarkan gambar 6 diketahui bahwa lingkungan sosial berada pada kategori rendah sebanyak 21 petani (42 persen). Hal ini disebabkan kurangnya dukungan dari keluarga, kerabat, lingkungan sekitar dan kemudahan dalam memperoleh informasi mengenai usahatani bawang putih baik dalam segi informasi harga pasar, informasi teknik budidaya serta informasi cara pemeliharaan, perawatan dari tanaman bawang putih. Selain itu, petani responden menganggap petani role model kurang menjadi faktor penting yang membuat petani responden termotivasi untuk mencapai tingkat yang sama dengan petani yang mereka anggap berhasil. Menurut Primadesi (2010) lingkungan sosial memiliki pengaruh kepada petani untuk melakukan tindakan lebih lanjut mengenai usahataninya. 


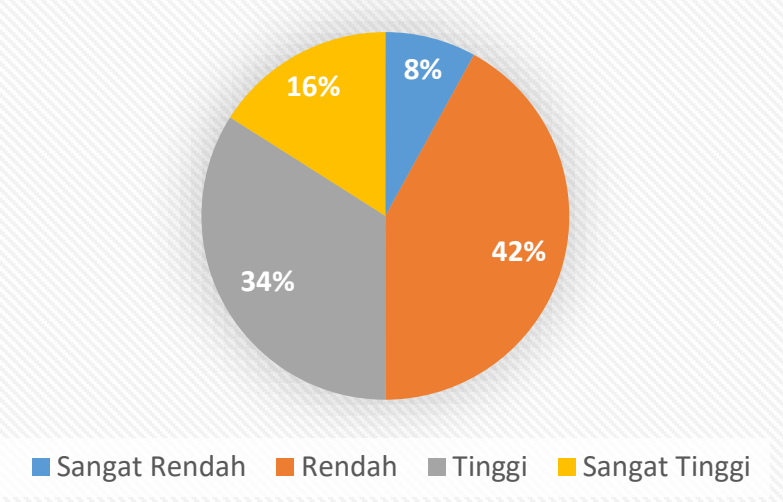

Gambar 6. Distribusi Responden Berdasarkan Lingkungan Sosial

Kegiatan pertanian selalu berkaitan dengan kekuatan ekonomi yang berkembang di sekitar masyarakat. Lingkungan ekonomi dapat memberikan pengaruh terhadap motivasi dalam berusahatani bawang putih dan dapat dilihat pada Gambar 7. Berdasarkan Gambar 7 diketahui bahwa lingkungan ekonomi mayoritas pada kategori rendah sebanyak 25 petani (50 persen). Kondisi lingkungan ekonomi dalam kategori rendah disebabkan oleh petani mendapatkan modal serta bibit bawang putih hanya dari hasil panen sebelumnya, peralatan yang mereka gunakan hanya peralatan sederhana dan alat seperti kultivator biasanya harus mengantre karena kultivator yang digunakan merupakan milik kelompok tani, serta pemasaran hasil dilakukan secara sederhana di sawah dengan pembeli langsung mendatangi lokasi panen. Menurut Mardikanto (1996) lingkungan ekonomi di sekitar petani akan memberikan pengaruh kepada petani terhadap kegiatan pertanian. Pada dasarnya kegiatan usaha pertanian adalah kegiatan ekonomi, maka pengaruh dari lingkungan ekonomi petani responden sangat besar pada kegiatan ekonomi yang akan dilakukan.

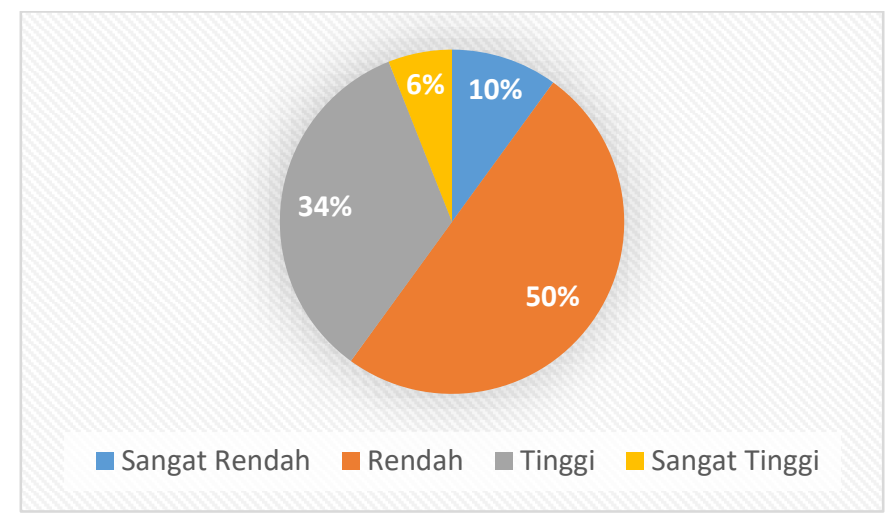

Gambar 7. Distribusi responden berdasarkan lingkungan ekonomi

Kelembagaan kelompok memberikan peran untuk mendukung dan membantu petani yang dapat memberikan pengaruh kepada petani dalam berusahatani, distribusi dapat dilihat pada Gambar 8 . Berdasarkan Gambar 8 diketahui bahwa kelembagaan kelompok tani berada pada kategori tinggi sebanyak 23 petani (46 persen). Hal ini karena adanya semangat petani dalam menghadiri pertemuan kelompok tani, semangat petani dalam berpartisipasi dalam kegiatan penyuluhan dan pelatihan yang diadakan oleh kelompok tani. Petani responden juga merasakan jika kelompok tani membantu pemasaran hasil meskipun hanya mencarikan pembeli untuk mendatangi lokasi. Menurut Rustandi \& Suhadji (2017) kelompok tani yang memberikan pengaruh besar dan berada pada kategori tinggi memiliki arti jika kelompok tani memperkuat kerja sama antara sesama petani dalam kelompok tani dan antar kelompok tani serta dengan pihak lain dengan pelaksanaan yang baik, berjalan secara berkelanjutan dan sesuai kebutuhan. 


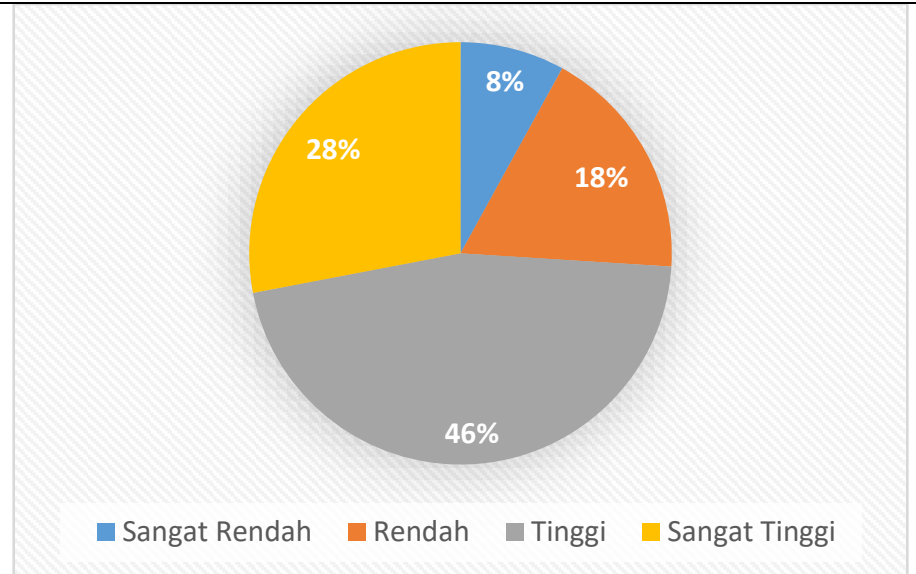

Gambar 8. Distribusi responden berdasarkan kelembagaan kelompok tani

Kebijakan dan dukungan yang diberikan oleh pemerintah/swasta dalam mendukung dan membantu petani dapat memberikan pengaruh kepada petani dalam berusahatani dapat dilihat pada Gambar 9. Berdasarkan Gambar 9 menunjukkan bahwa dukungan pemerintah/swasta berada pada kategori rendah sebanyak 21 petani (42 persen) yang disebabkan karena petani responden merasa bantuan yang diterima berupa fasilitas pupuk, benih, dan pestisida masih kurang, teknologi yang di berikan seperti sepeda roda tiga, kultivator harus digunakan secara bergantian karena jumlahnya yang terbatas. Selain itu juga petani kurang merasakan adanya jaminan dan kepastian harga dari pemerintah di mana petani ketika memasarkan hasil produksi mereka dari tiap musim selalu beda. Seharusnya pemerintah harus lebih tegas dalam mengatur sistem harga bawang putih. Sejalan dengan Rondhi \& Ridjal (2016) dimana pemerintah mempunyai peran dalam mempengaruhi dan menentukan harga dengan berbagai mekanisme seperti penentuan harga tertinggi, penentuan harga terendah, penentuan pajak, dan ketentuan proteksi dari perdagangan luar negeri.

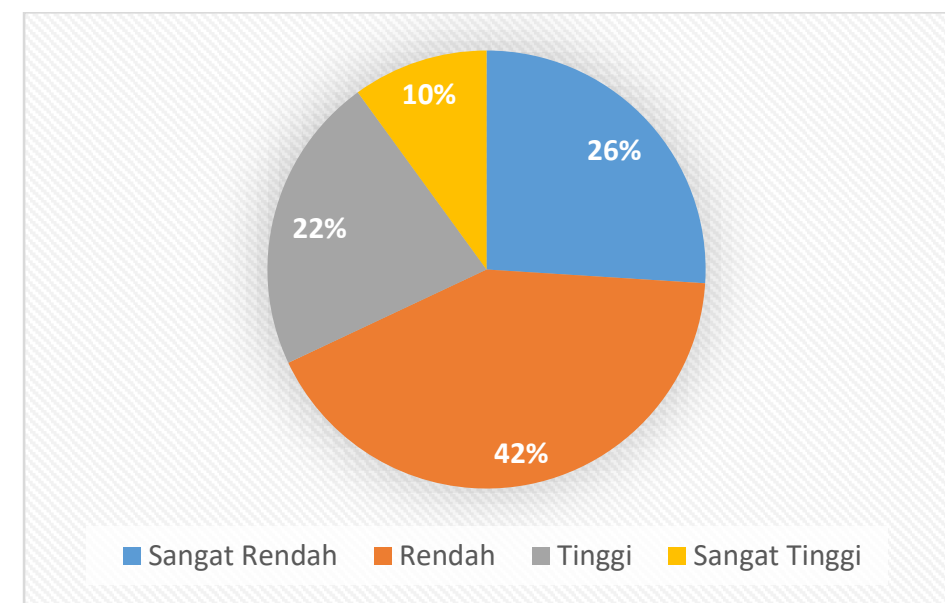

Gambar 9. Distribusi responden berdasarkan dukungan pemerintah/swasta

\subsection{Tingkat Motivasi dalam Usahatani Tanaman Bawang Putih}

Tabel 1 menunjukkan bahwa motivasi petani responden berdasarkan kebutuhan fisiologis berada pada kategori sangat tinggi sebanyak 18 orang (36 persen). Kebutuhan fisiologis dibedakan menjadi dua yaitu kebutuhan fisiologis primer dan sekunder. Kebutuhan primer menunjukkan jika petani responden sudah mampu untuk mencukupi kebutuhan dasar mereka meliputi kebutuhan sandang, pangan dan papan. Kebutuhan sekunder menunjukkan jika petani responden sudah mampu mencukupi kebutuhan sekunder berupa kebutuhan hiburan, liburan, pendidikan. Hasibuan (2001) menerangkan jika kebutuhan fisiologis merupakan kebutuhan utama dan kebutuhan yang harus dipenuhi, jika kebutuhan fisiologis belum terpenuhi maka akan berdampak dengan munculnya perasaan tidak tenang dan sejalan dengan itu, seseorang pasti akan berusaha untuk memenuhinya. 
Tabel 1. Distribusi responden berdasarkan tingkat motivasi petani

\begin{tabular}{lllccc}
\hline No. & \multicolumn{1}{c}{ Kategori } & \multicolumn{1}{c}{ Kategori } & Skor & Jumlah & $(\%)$ \\
\hline 1 & Kebutuhan Fisiologis & Sangat Tinggi & $6,53-8,03$ & 18 & 36 \\
2 & Kebutuhan Rasa Aman & Rendah & $3,51-5,01$ & 23 & 46 \\
3 & Kebutuhan Sosial & Sangat Tinggi & $6,53-8,03$ & 27 & 54 \\
4 & Kebutuhan Penghargaan & Sangat Rendah & $2,00-3,50$ & 22 & 44 \\
5 & Kebutuhan Aktualisasi Diri & Rendah & $3,51-5,01$ & 16 & 32 \\
\hline
\end{tabular}

Tabel 1 menunjukkan jika motivasi petani responden berdasarkan kebutuhan rasa aman berada pada kategori rendah sebanyak 23 orang (46 persen). Hal ini dipengaruhi oleh anggapan petani yang merasa kurang adanya perlindungan antar sesama petani bawang putih. Hal ini tidak sejalan dengan Saputra et al. (2017) jika dalam berkegiatan usahatani, diperlukan adanya rasa aman, karena petani ingin dalam setiap kegiatan usahataninya tidak diliputi rasa ketakutan. Diperlukannya kesadaran akan perlindungan dari sesama petani, dan jika rasa aman tercipta, maka petani akan termotivasi dalam melakukan usahatani tanaman bawang putih.

Tabel 10 menjelaskan jika motivasi petani responden berdasarkan kebutuhan sosial berada pada kategori sangat tinggi sebanyak 27 orang (54 persen). Hal ini dapat didasari karena petani menganggap dengan menanam bawang putih, petani dapat dengan mudah berinteraksi dengan lingkungan sekitar di mana lingkungan sekitar tempat petani tinggal juga merupakan lingkungan pertanian bawang putih. Petani responden juga merasakan dukungan dengan sesama petani berupa kemudahan dalam menjalin kerja sama saling membantu dalam usahatani dan dapat saling bertukar pendapat mengenai teknik usahatani. Menurut Saputra et al. (2017) kebutuhan sosial yang tinggi sangat dipengaruhi oleh sikap petani yang saling membutuhkan satu sama lain dalam kaitannya berdiskusi atau memberi dorongan agar usahataninya menjadi lebih baik.

Tabel 1 menjelaskan jika motivasi petani responden berdasarkan kebutuhan penghargaan dalam kategori sangat rendah dengan jumlah petani responden sebanyak 22 orang (44 persen). Petani responden beranggapan jika pujian hanya didapat ketika mereka mendapatkan hasil panen yang benarbenar bagus. Dengan hasil panen yang sangat bagus tersebut petani otomatis akan mendapatkan pujian dari lingkungan sekitar, kelompok tani yang dia ikuti, bahkan dari para petani dari luar desa yang dia tempati. Namun petani responden merasa jika hasil panen yang sangat bagus itu jarang ditemui, sehingga pujian yang diterima juga hampir tidak pernah mereka terima. Saputra et al. (2017) menerangkan kaitannya penghargaan merupakan sifat alamiah setiap orang. Rasa penghargaan tersebut diperoleh dari hasil yang dicapai oleh setiap individu, dan setiap individu memiliki kriteria berbeda dalam mengapresiasi individu lain.

Tabel 1 menunjukkan bahwa motivasi petani responden berdasarkan kebutuhan penghargaan berada pada kategori rendah sebanyak 16 orang (44 persen). Rendahnya mayoritas petani responden menunjukkan jika petani responden dalam berusahatani kurang mengembangkan, kurang melatih dan kurang meningkatkan kreativitas serta keterampilan yang ada dalam diri mereka masing-masing. Rendahnya kebutuhan aktualisasi diri juga menjelaskan jika petani responden kurang menginginkan untuk menjadi petani model, petani yang dianggap sukses dan dianggap menjadi panutan serta tolak ukur bagi petani lain. Menurut Salahuddin et al. (2017) motivasi berdasarkan faktor aktualisasi diri petani yang tergolong rendah dipengaruhi karena kurang puasnya petani dengan hasil produksi pertaniannya.

Penggunaan dari teori kebutuhan Maslow didasari karena teori kebutuhan Maslow merupakan salah satu teori yang mendasari dari perkembangan teori motivasi lainnya dan berorientasi pada kebutuhan manusia. Teori kebutuhan Maslow memberikan informasi bahwa kebutuhan manusia itu beragam dan variatif serta memiliki tingkatan serta ada jenjang dalam memenuhi kebutuhan manusia. Menurut Hasibuan (2007) dalam Sari dan Dwiarti (2018) kelebihan dari teori motivasi Maslow yang pertama teori ini menjelaskan jika kebutuhan manusia itu jamak (materiil dan nonmateriil) dan memiliki bobot yang bertingkat. Kedua, dapat memenuhi kebutuhan (materiil dan non-materiil) yang dapat memberikan kepuasan seseorang. Ketiga, kebutuhan manusia memiliki jenjang sesuai kedudukan maupun sosial ekonominya. Seseorang yang berkedudukan rendah dipengaruhi oleh motivasi oleh materiil, sedangkan orang yang berkedudukan tinggi motivasinya dipengaruhi oleh non materiil. 
Keempat, lebih mudah memberikan faktor-faktor motivasi yang digunakan sebagai alat paling sesuai untuk merangsang semangat bekerja.

Pengaplikasian teori motivasi berdasarkan tingkatan kebutuhan dari Abraham Maslow jika dilihat berdasarkan hasil analisis, diketahui kurang cocok untuk diaplikasikan pada penelitian ini karena hasil didapat kurang memuaskan, hanya kebutuhan fisiologis dan kebutuhan sosial yang dapat digolongkan pada kategori sangat tinggi. Menurut Dewi et al. (2016) teori hierarki kebutuhan Maslow terbilang kaku. Teori hierarki kebutuhan Maslow menjelaskan bahwa seseorang akan tetap berada di tingkat kebutuhan tertentu sampai kebutuhannya tersebut terpuaskan, jika kebutuhan itu terpuaskan makan mereka akan naik ke tingkat selanjutnya. Menurut Hasibuan (2007) dalam Sari dan Dwiarti (2018) kelemahan dari teori motivasi Maslow yang pertama, kebutuhan manusia memiliki tingkatan, tetapi dalam kenyataannya manusia selalu menginginkan semua kebutuhannya tercapai sekaligus. Kedua, belum pernah dicoba kebenarannya, karena Maslow mengembangkan teori ini berdasarkan pengamatan saja.

Motivasi petani dalam usahatani bawang putih dapat dikatakan sebagai alasan yang mendasari dari petani itu sendiri untuk berkeinginan menanam bawang putih. Petani dalam menanam bawang putih memiliki alasan selain untuk mencukupi kebutuhan petani dari kebutuhan fisiologis, kebutuhan rasa aman, kebutuhan sosial, kebutuhan penghargaan, dan kebutuhan aktualisasi diri juga terdapat alasan lain, alasan tersebut berupa adanya kebudayaan turun-temurun dari dulu untuk menanam bawang putih. Karena pada jaman dulu bawang putih merupakan komoditas andalan/unggulan, selain itu karena data produktivitas bawang putih yang tinggi dibandingkan dengan kecamatan lain atau daerah lain di Kabupaten Karanganyar. Bawang putih juga memiliki nilai jual yang lebih tinggi dibandingkan dengan tanaman jenis lainnya. Proses penanaman bawang putih juga terbilang lebih mudah, namun risiko kegagalan panen juga yang paling tinggi karena bawang putih sangat rentan dipengaruhi oleh cuaca. Tanaman bawang putih sangat bagus ditanam di musim kemarau, jika terdapat hujan meskipun hujannya sedikit, hal tersebut sangat berefek pada kondisi tanaman bawang putih serta dapat dimungkinkan jika hasil panen bawang putih dari petani akan jatuh dan cenderung rugi. Produksi dan luas panen tanaman bawang putih di Kecamatan Tawangmangu pada tahun 2017-2019 menunjukkan jika data produksi dan luas panen selalu mengalami peningkatan. Namun pada saat pengambilan data ke lapang, didapat informasi dari petani responden dan penyuluh pertanian Kecamatan Tawangmangu jika pada tahun 2020 atau pada panen terakhir petani mengalami gagal panen dan mengalami kerugian, sangat berbeda jika dibandingkan dengan data pada tahun sebelum-sebelumnya. Petani mau menanam bawang putih juga karena adanya program dari pemerintah untuk swasembada bawang putih.

\subsection{Hubungan antara Faktor- Faktor Pembentuk Motivasi dengan Motivasi Petani dalam Usahatani Bawang Putih}

Tabel 2 menunjukan nilai koefisien korelasi $\left(r_{S}\right)$ antara variabel umur dan motivasi total sebesar $-0,038$ dengan nilai Sig. (2-tailed) $0,792>\alpha$ : 0,05 yang berarti umur tidak berhubungan signifikan dan menjelaskan jika perbedaan umur / bertambahnya umur petani tidak berhubungan dengan motivasi. Sejalan dengan Astuti (2014) yang menjelaskan bahwa umur tidak memiliki hubungan dalam usahataninya karena umur tidak memberikan jaminan dalam peningkatan motivasi. Umur hanya berpengaruh terhadap pengalaman tetapi pengalaman juga tidak berpengaruh terhadap motivasi petani. Umur petani produktif maupun tidak produktif, tidak berpengaruh terhadap motivasi dalam usahatani bawang putih.

Nilai koefisien korelasi $\left(r_{S}\right)$ variabel pendidikan formal dengan motivasi total sebesar $-0,265$ dengan nilai Sig. (2-tailed) 0,063 $>\alpha$ : 0,05 yang berarti pendidikan formal tidak berhubungan signifikan dan menunjukkan bahwa tinggi rendahnya pendidikan tidak berhubungan dengan motivasi petani. Sejalan dengan hasil penelitian Saputra et al. (2017) tidak terdapatnya hubungan antara pendidikan dengan motivasi petani karena tingkat dalam berusahatani tidak harus memiliki keahlian dan kelebihan khusus dalam mengelola usahataninya dan dapat dilakukan oleh siapa saja tanpa perlu berpendidikan tinggi.

Tabel 2 menunjukan nilai koefisien korelasi $\left(r_{S}\right)$ sebesar 0,292 dengan nilai Sig. (2-tailed) 0,040 $<\alpha$ : 0,05 yang berarti luas lahan (X3) yang dimiliki petani berhubungan positif signifikan dengan motivasi petani. Petani responden memiliki luas lahan yang tinggi karena di daerah Kecamatan Tawangmangu merupakan daerah dengan potensi pertanian yang sangat baik. Luas lahan yang berpengaruh signifikan terhadap motivasi petani dalam usahatani bawang putih juga sejalan dengan 
penelitian Martin dan Galle (2009) di mana luas lahan yang di Kelola oleh petani dengan motivasi petani mempunyai hubungan yang sangat berkesinambungan.

Tabel 2. Signifikansi Hubungan antara Faktor-Faktor Pembentuk Motivasi dengan Tingkat Motivasi Petani dalam Usahatani Bawang Putih

\begin{tabular}{lrrrrrr}
\hline Variabel & $\begin{array}{c}\text { Kebutuhan } \\
\text { Fisiologis }\end{array}$ & \multicolumn{1}{c}{$\begin{array}{c}\text { Kebutuhan } \\
\text { Rasa Aman }\end{array}$} & $\begin{array}{c}\text { Kebutuhan } \\
\text { social }\end{array}$ & $\begin{array}{c}\text { Kebutuhan } \\
\text { penghargaan }\end{array}$ & $\begin{array}{c}\text { Kebutuhan } \\
\text { aktualisasi diri }\end{array}$ & $\begin{array}{c}\text { Motivasi } \\
\text { total }\end{array}$ \\
\hline X1 & 0,137 & $-0,123$ & $-0,169$ & $-0,058$ & $-0,044$ & $-0,038$ \\
X2 & $-0,234$ & $-0,067$ & $-0,040$ & $-0,270$ & $-0,276$ & $-0,265$ \\
X3 & 0,039 & $0,318^{*}$ & 0,192 & 0,253 & $0,296^{*}$ & $0,292^{*}$ \\
X4 & $0,292^{*}$ & $0,424^{* *}$ & $0,283^{*}$ & $0,363^{* *}$ & $0,345^{*}$ & $0,481^{* *}$ \\
X5 & $0,283^{*}$ & 0,087 & $-0,069$ & 0,131 & 0,105 & 0,159 \\
X6 & 0,120 & $0,571^{* *}$ & $0,321^{*}$ & $0,437^{* *}$ & $0,402^{* *}$ & $0,506^{* *}$ \\
X7 & $0,339^{*}$ & $0,575^{* *}$ & $0,708^{* *}$ & $0,608^{* *}$ & $0,470^{* *}$ & $0,668^{* *}$ \\
X8 & $-0,127$ & $0,331^{*}$ & 0,189 & 0,234 & $0,395^{*}$ & $0,287^{*}$ \\
X9 & 0,069 & $0,331^{*}$ & 0,231 & 0,189 & $0,420^{* *}$ & $0,283^{*}$ \\
\hline
\end{tabular}

Keterangan: signifikan pada taraf nyata $* 5 \%$ dan $* * 1 \%$

Nilai koefisien korelasi $\left(r_{S}\right)$ pendapatan (X4) sebesar 0,481 dengan nilai Sig. (2-tailed) 0,000 < $\alpha$ : 0,01 yang berarti terdapat hubungan positif yang signifikan dan pendapatan yang diperoleh dari hasil usahatani bawang putih berpengaruh dengan motivasi petani. Sejalan dengan Dewi et al. (2016) yang menjelaskan pendapatan memiliki hubungan yang nyata dengan motivasi petani berusahatani. Pendapatan yang bertambah akan meningkatkan kesejahteraan dari petani. Hal ini sejalan juga dengan Ekalinda (2017) dimana tingkat pendapatan petani tergolong rendah namun menunjukan pengaruh yang erat dengan motivasi ekonomi petani dan motivasi afiliasi ssedangkan motivasi prestasi menunjukkan pengaruh yang lemah.

Tabel 2 menunjukan nilai koefisien korelasi $\left(r_{S}\right)$ pengalaman (X5) sebesar 0,159 dengan nilai Sig. (2-tailed) 0,271 $>\alpha$ : 0,05 yang berarti pengalaman tidak berhubungan signifikan dan menunjukkan bahwa lama atau tidaknya pengalaman tidak berpengaruh dengan motivasi petani. Selain itu pengalaman petani dapat dikategorikan sebagai sumber informasi dari petani, dan pengalaman tidak bisa dijadikan dasar apakah petani yang memiliki pengalaman yang lebih lama berpengaruh terhadap kegiatan usahatani dengan lebih baik. Hal ini sejalan dengan Astuti (2014) jika pengalaman tidak mempengaruhi motivasi petani dalam berusahatani. Pada dasarnya dalam berusahatani, pengalaman dalam berusahatani bawang putih, jika semakin lama pengalamannya akan dapat menambah motivasi lebih pada petani untuk berusahatani bawang putih, namun kenyataannya pengalaman tidak mempengaruhi motivasi petani.

Nilai koefisien korelasi $\left(r_{S}\right)$ kondisi lingkungan social (X6) sebesar 0,506 dengan nilai Sig. (2tailed) $0,000<\alpha: 0,01$ yang berarti terdapat hubungan yang sangat signifikan positif. Hal ini menunjukkan kondisi lingkungan sosial petani responden sangat mendukung petani dalam berusahatani bawang putih. Dengan kata lain, lingkungan social yang mendukung akan mendorong motivasi petani. Sejalan dengan Primadesi (2010) lingkungan sosial yang mendukung akan mendorong petani termotivasi dalam melakukan kegiatan usahataninya. Mardikanto (2003) dalam Pangestika et al. (2017) menyatakan bahwa lingkungan sosial memberikan pengaruh yang sangat besar terhadap masyarakat. Lingkungan sosial berpengaruh kepada perubahan kebudayaan, pengambilan keputusan dalam keluarga, opini public di lingkungan petani dan kekuatan lembaga sosial. Kebudayaan memberikan pengaruh besar karena petani responden dalam melakukan kegiatan pertanian berawal dari turun-temurun dari orang tuanya.

Nilai koefisien korelasi $\left(r_{S}\right)$ lingkungan ekonomi (X7) sebesar 0,668 dengan nilai Sig. (2-tailed) $0,000<\alpha: 0,01$ yang berarti terdapat hubungan yang sangat signifikan positif. Hal ini menunjukkan bahwa kondisi lingkungan ekonomi petani responden memiliki hubungan positif terhadap motivasi petani dalam berusahatani. Lingkungan ekonomi juga dipengaruhi oleh faktor berupa sarana produksi yaitu benih, pupuk, pestisida serta faktor peralatan produksi yang cukup mendukung petani. Rukka dan Wahab (2013) menjelaskan jika motivasi petani dalam menerapkan suatu inovasi dalam usahataninya sangat dipengaruhi oleh ketersediaan dan dukungan sarana produksi pertanian yang sesuai dan tepat waktu. Mardikanto (1996) dalam Pangestika et al. (2017) menjelaskan jika lingkungan ekonomi di 
sekitar petani sangat berpengaruh terhadap kegiatan pertanian. Dikarenakan usaha pertanian merupakan kegiatan ekonomi, merupakan sebuah pengaruh besar jika kegiatan ekonomi dipengaruhi oleh lingkungan ekonomi petani.

Tabel 2 menunjukan nilai koefisien korelasi $\left(r_{S}\right)$ kelompok tani (X8) sebesar 0,287 dengan nilai Sig. (2-tailed) $0,043<\alpha: 0,05$ yang berarti terdapat hubungan yang signifikan dan bertanda positif. Kondisi ini menunjukkan jika kelompok tani memiliki hubungan positif terhadap motivasi petani dalam kegiatan berusahatani bawang putih. Petani responden beranggapan jika kelompok tani sangat penting keberadaannya. Selain tempat untuk bertukar ilmu, baik ilmu tentang budidaya dari awal tanam hingga proses panen dan pemasaran, kelompok tani juga berguna sebagai tempat untuk mendapatkan informasi. Petani responden yang mengikuti kelompok tani rutin menghadiri pertemuan kelompok tani. Menurut Astuti (2014) yang menjelaskan bahwa intensitas pertemuan yang diselenggarakan kelompok tani dan kegiatan penyuluhan merupakan upaya untuk meningkatkan motivasi pada petani dalam kegiatan pertanian, dalam hal ini adalah kegiatan usahatani bawang putih.

Nilai koefisien korelasi $\left(\boldsymbol{r}_{\boldsymbol{S}}\right)$ dukungan pemerintah/swasta (X9) dengan motivasi petani sebesar 0,283 dengan nilai Sig. (2-tailed) $0,046<\alpha: 0,05$ yang berarti terdapat hubungan positif yang signifikan. Hal ini menunjukkan bahwa peran pemerintah/swasta sangat membantu petani sehingga memiliki hubungan positif terhadap motivasi petani dalam kegiatannya berusahatani bawang putih. Adanya bantuan dari pemerintah akan memberikan dorongan kepada petani untuk melakukan kegiatan usahatani bawang putih. Selain itu pemerintah juga masih memberikan subsidi kepada petani agar petani tidak merasa terbebani dalam memperoleh sarana produksi untuk menunjang kegiatan usahataninya. Penyelenggaraan penyuluhan serta pelatihan juga dianggap petani berpengaruh terhadap motivasinya untuk berusahatani bawang putih. Menurut Dewi et al. (2016) kegiatan penyuluhan pertanian merupakan pendidikan non formal bagi petani yang bermanfaat untuk meningkatkan kemampuan petani dalam bidang usahatani. Petani akan memiliki pola pikir yang lebih terbuka sehingga memberikan pengaruh terhadap kemampuannya untuk mengatasi permasalahan yang di hadapi dalam kegiatan usahatani.

\section{KESIMPULAN DAN SARAN}

\subsection{Kesimpulan}

Hasil penelitian menunjukkan bahwa : (1) Tingkat motivasi petani responden berdasarkan kebutuhan fisiologis berada pada kategori sangat tinggi, berdasarkan kebutuhan rasa aman berada pada kategori rendah, berdasarkan kebutuhan sosial berada pada kategori sangat tinggi, berdasarkan kebutuhan penghargaan berada pada kategori sangat rendah, dan berdasarkan kebutuhan aktualisasi diri berada pada kategori rendah. (2) faktor pembentuk motivasi pada variabel umur petani berada pada rentang usia 46-555 tahun. Pendidikan formal petani didominasi lulusan SD. Luas lahan di dominasi pada rentang $510-1.000 \mathrm{~m} 2$. Pendapatan petani berada pada kategori sangat rendah. Pengalaman petani berada dalam kategori sangat tinggi dimana lebih dari 20 tahun, Lingkungan sosial di dominasi kurangnya faktor dukungan dari kehidupan sosial di sekitarnya, Lingkungan ekonomi di dominasi rendahnya dalam mendapatkan alat penunjang pertanian, Kelembagaan di dominasi oleh tingginya semangat petani dalam mengikuti kegiatan kelompok tani dan Dukungan pemerintah di dominasi oleh kurangnya jumlah bantuan yang di terima kepada petani; (3) Terdapat hubungan yang sangat signifikan antara faktor pendapatan, lingkungan sosial, dan lingkungan ekonomi dengan motivasi petani. Terdapat hubungan yang signifikan antara faktor luas lahan, kelembagaan kelompok tani dan dukungan pemerintah/swasta dengan motivasi petani. Tidak terdapat hubungan yang signifikan antara faktor umur, pendidikan dan pengalaman dengan motivasi petani.

\subsection{Saran}

Dilihat dari kepemilikan luas lahan petani diharapkan untuk lebih mengoptimalkan kegiatan usahataninya karena dapat memberikan hasil produksi yang maksimal. Dilihat dari faktor lingkungan sosial, petani diharapkan untuk lebih meningkatkan interaksinya dengan lingkungan sosialnya. Dilihat dari faktor kelembagaan kelompok tani dan dukungan pemerintah/swasta, diharapkan adanya peran lebih dari pemerintah maupun kelompok tani untuk membantu dalam pemasaran bawang putih agar pemasaran yang dilakukan oleh petani lebih baik tidak hanya melakukan pemasaran di lahan saja. 


\section{DAFTAR PUSTAKA}

Arifin, Z., Rosyani, \& Suandi. (2017). Hubungan Kebutuhan Petani Dalam Pelaksanaan Usahatani Dengan Sistem Pengelolaan Gilir Ganti Padi Sawah (Studi Kasus Di Desa Mukai Mudik Kecamatan Siulak Mukai Kabupaten Kerinci). Jurnal Ilmiah Sosio Ekonomika Bisnis, Vol 20. (1) 2017. DOI:https://doi.org/10.22437/jiseb.v20i1.5036

Astuti, R. P. (2014.) Motivasi Petani Dalam Usahatani Padi Organik Di Kecamatan Pandak Kabupaten Bantul. Skripsi Program Studi Agribisnis, Fakultas Pertanian, Universitas Muhammadiah Yogyakarta. URL: http://repository.umy.ac.id/handle/123456789/8140.

Daniel, M. (2002). Pengantar Ekonomi Pertanian. Jakarta: Bumi Aksara.

Dewi, M. M., Bekti, W. \& Utami, H. I. (2016). Motivasi Petani Berusahatani Padi (Kasus Di Desa Gunung Kecamatan Simo Kabupaten Boyolali. Jurnal Agrista, Vol. 4 (3):104-114.

Ekalinda, O. (2017). Hubungan Faktor - Faktor Intern Petani Dengan Tingkat Motivasinya Dalam Penerapan Adopsi Teknologi Inovasi Pada Taman Teknologi Pertanian (Ttp) Siak. Jurnal Buletin Inovasi Pertanian, Vol. 3 (1) : 21-27.

Hasibuan, M. (2006). Dasar-dasar, Pengertian, dan Masalah Dalam Manajemen. Jakarta : Bumi aksara Hasibuan, M. (2007). Organisasi dan Motivasi : Dasar Peningkatan Produktivitas. Cetakan ke-5. Jakarta : PT. Bumi Aksara.

Hasyim, H. (2006). Analisis Hubungan Karakteristik Petani Kopi Terhadap Pendapatan (Studi kasus: Desa Dolok Seribu Kecamatan Paguran Kabupaten Tapanuliutara). Jurnal Komunikasi Penelitian, Vol. 18 (1): 23-27.

Hasyim, H. (2003). Analisis Hubungan Faktor Sosial Ekonomi Petani Terhadap Program Penyuluhan Pertanian. Laporan Hasil Penelitian. Universitas Sumatera Utara, Medan.

Mardikanto, T. (1996). Penyuluhan Pembangunan Kehutanan. Pusat Penyuluhan Kehutanan Departemen Kehutanan Republik Indonesia Bekerjasama Dengan Fakultas Pertanian Universitas Sebelas Maret Surakarta. Jakarta

Martin, E. \& Galle, F. B. (2009). Motivasi Dan Karakteristik Sosial Ekonomi Rumah Tangga Penanam Pohon Penghasil Kayu Pertukangan : Kasus Tradisi Menanam Kayu Bawang (Disoxylum Molliscimum Bl) Oleh Masyarakat Kabupaten Bengkulu Utara, Bengkulu. Jurnal Penelitian Sosial Dan Ekonomi Kehutanan, Vol. 6 (2):117-134.

Maslow, A. H. (1994). Motivasi dan Kepribadian : Teori Motivasi dengan Pendekatan Hierarki Kebutuhan Manusia. Bandung : T Pustaka Binaman Pressindo

Pangestika, D. N., Lestari, E. \& Sutarto. (2017). Hubungan Antara Karakteristik Sosial Ekonomi Dengan Tingkat Motivasi Petani Dalam Alih Fungsi Lahan Sawah Menjadi Kolam Ikan Di Kecamatan Polanharjo Kabupaten Klaten. Jurnal Agritexts, Vol. 41 (1): 1-14.

Phahlevi, R. (2007). Faktor-Faktor Yang Mempengaruhi Pendapatan Petani Padi Sawah Di Kota Padang Panjang. Skripsi Program Sarjana Universitas Negeri Padang. Padang.

Primadesi, F. 2010. Motivasi Petani dalam Budidaya Tanaman Buah Naga di Kecamatan Bendosari Kabupaten Sukoharjo. Skripsi tidak diterbitkan Fakultas Pertanian Universitas Sebelas Maret Surakarta.

Rondhi, M \& Ridjal, J. A. (2016). Kebijakan Dan Peraturan Bidang Pertanian. Fakultas Pertanian Universitas Jember

Rukka, H. \& Wahb, A. (2013). Faktor-faktor Yang Mempengaruhi Motivasi Petani Dalam Pelaksanaan Kegiatan P2BN DI Kecamatan Barru, Kabupaten Barru. Jurnal Agrisistem, Vol. 1 (9):46-56.

Rustandi, Y. \& Suhadji, R. (2017). Keragaan Evaluasi Fungsi Kelembagaan Kelompok Tani Di Kecamatan Papar Kabupaten Kediri Jawa Timur. Jurnal Agrica Ekstensia, Vol. 11 (2): 55-60.

Salahuddin, M. \& Wasariana. (2017). Hubungan Tingkat Pengetahuan Dengan Motivasi Petani Dalam Usahatani Padi Sawah Di Desa Tanjung Batu Kecamatan Kabawo Kabupaten Muna. Jurnal Buletin Sosek, Vol. 19(35): 50-60.

Saputra, G. R. \& Isyaturriyadhah, P. (2017). Faktor Sosial Ekonomi Yang Memotivasi Petani Dalam Usahatani Jahe Di Kecamatan Renah Pembarap Kabupaten Merangin. Jurnal Agri Sains, Vol. 1 (2).

Sari, E \& Dwiarti, R. (2018). Pendekatan Hierarki Abraham Maslow Pada Prestasi Kerja Karyawan Pt. Madubaru (PG MADUKISMO) Yogyakarta. Jurnal JPSB, Vol. 6 (1) : 58-77. 